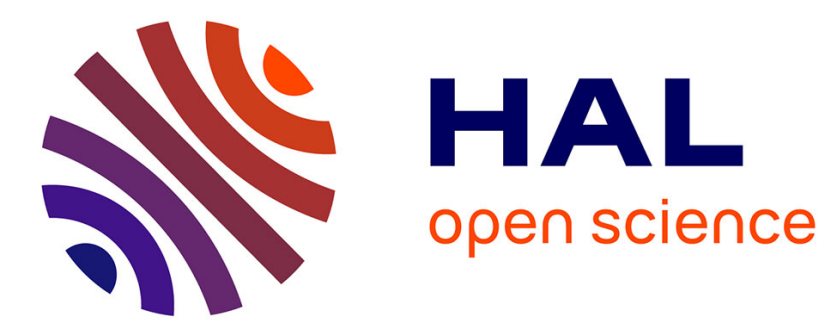

\title{
U.S. strategic solar photovoltaic-powered microgrid deployment for enhanced national security
}

\author{
Emily Prehoda, Chelsea Schelly, Joshua Pearce
}

\section{To cite this version:}

Emily Prehoda, Chelsea Schelly, Joshua Pearce. U.S. strategic solar photovoltaic-powered microgrid deployment for enhanced national security. Renewable and Sustainable Energy Reviews, 2017, 78, pp.167-175. 10.1016/j.rser.2017.04.094 . hal-02113459

\section{HAL Id: hal-02113459 \\ https://hal.science/hal-02113459}

Submitted on 28 Apr 2019

HAL is a multi-disciplinary open access archive for the deposit and dissemination of scientific research documents, whether they are published or not. The documents may come from teaching and research institutions in France or abroad, or from public or private research centers.
L'archive ouverte pluridisciplinaire HAL, est destinée au dépôt et à la diffusion de documents scientifiques de niveau recherche, publiés ou non, émanant des établissements d'enseignement et de recherche français ou étrangers, des laboratoires publics ou privés. 
Preprint: Emily W. Prehoda, Chelsea Schelly, Joshua M. Pearce. 2017. U.S. Strategic Solar Photovoltaic-Powered Microgrid Deployment for Enhanced National Security. Renewable \& Sustainable Energy Reviews 78, 167-175. DOI:10.1016/j.rser.2017.04.094

\title{
U.S. Strategic Solar Photovoltaic-Powered Microgrid Deployment for Enhanced National Security
}

\author{
Emily W. Prehoda ${ }^{\mathrm{a}}$, Chelsea Schelly ${ }^{\mathrm{a}}$, Joshua M. Pearce ${ }^{\mathrm{b}, \mathrm{c}, *}$ \\ ${ }^{a}$ Department of Social Sciences, Michigan Technological University, 1400 Townsend Drive, Houghton, Michigan 49931-1295, USA \\ ${ }^{\mathrm{b}}$ Department of Materials Science and Engineering, Michigan Technological University, 1400 Townsend Drive, Houghton, Michigan \\ 49931-1295, USA \\ ${ }^{\mathrm{c}}$ Department of Electrical and Computer Engineering, Michigan Technological University, 1400 Townsend Drive, Houghton, Michigan \\ 49931-1295, USA \\ *Corresponding author. E-mail: pearce@mtu.edu.
}

\begin{abstract}
The U.S. electrical grid, the largest and most complex man-made system in the world, is highly vulnerable to three types of external threats: 1) natural disasters, 2) intentional physical attacks, and 3) cyber-attacks. The technical community has recommended hardening the grid to make it more resilient to attack by using distributed generation and microgrids. Solar photovoltaic (PV) systems are an ideal distributed generation technology to provide power for such microgrids. However, both the deployment velocity and the policy of how to implement such technical solutions have been given far less attention than would be normally considered adequate for a national security risk. To address this threat, this paper reviews the technical and economic viability of utilizing defense contracting for the beginning of a national transition to distributed generation in the U.S. First, the technical scale of electrical demand and the solar PV system necessary is analyzed in detail to meet the first level of strategic importance: the U.S. military. The results found that about 17GW of PV would be needed to fortify the U.S. military domestically. The current domestic geographic deployment of microgrid installations in the critical U.S. defense infrastructure were reviewed and compared to historical grid failures and existing and planned PV installations to mitigate that risk. The results showed a minimal number of military bases have introduced solar PV systems, leaving large parts of the Department of Defense electrical infrastructure vulnerable to attack. To rectify this situation, the technical skills of the top 20 U.S. defense contractors is reviewed and analyzed for a potential contracting transition to grid fortification. Overall the results indicate that a fortified U.S. military grid made up of PV-powered microgrids is technically feasible, within current contractors skill sets and economically viable. Policy recommendations are made to accelerate U.S. military grid fortification.
\end{abstract}

Keywords: national security; photovoltaic; resilience; microgrid; defense; distributed generation

\section{Introduction}

The U.S. electrical grid, the largest and most complex man-made system in the world today [1], is an interconnected network for delivering electricity from generally centralized suppliers to distributed consumers. This electrical system architecture is comprised of substations with variable carrying capacities of electrical load, which are susceptible to widespread cascading failures [1-3]. Every U.S. sector (military, economy, government, health care, education, etc.) depends on the grid to deliver essential electrical services. Due to its highly interconnected and interdependent nature, electric grid failure has the potential to impair economic and social functions in the event of a power outage [4-6]. The interdependencies of the power grid and other critical infrastructures are illustrated in Figure 1. The general consensus in the energy community is that the electrical grid is highly vulnerable to three types of external threats: 1) natural disasters [7-9], 2) intentional physical attacks [5, 10-13], and 3) cyber-attacks [14-20].

The first threat of natural disasters caused by severe weather is responsible for $\$ 18$ to $\$ 33$ billion every year in power outages and damages to U.S. infrastructure [23]. These major power outage disasters tend to be 
Preprint: Emily W. Prehoda, Chelsea Schelly, Joshua M. Pearce. 2017. U.S. Strategic Solar Photovoltaic-Powered Microgrid Deployment for Enhanced National Security. Renewable \& Sustainable Energy Reviews 78, 167-175. DOI:10.1016/j.rser.2017.04.094

widespread, with an average of 700,000 consumers impacted per weather-induced power outage annually [5]. The impacts of past major U.S. power outages are summarized in Table 1. The majority of economic costs result from spoiled inventory, delayed production, and damage to grid infrastructure [23].

The second threat of physical attacks includes traditional acts of terrorism such as bombing or sabotage [14] (e.g. an electromagnetic pulse attack [24-26]). The traditional power grid infrastructure is incapable of withstanding intentional physical attacks [27]. Damage resulting in physical attack could be long lasting, as power plants operate with large transformers that are difficult to move and source. Custom rebuilt transformers require time for replacement ranging from months and even up to years [27]. For example, a 2013 sniper attack on California's Pacific Gas and Electric (PG\&E) substation disabled 17 transformers supplying power to Silicon Valley. Repairs and improvements cost PG\&E roughly \$100 million and lasted 27 days [28-30].

In addition to physical attacks, the electrical grid is also exposed to cyber-attacks. The Pentagon reports spending roughly $\$ 100$ million to repair cyber-related damages to the electric grid in 2009 [31]. The U.S. electric grid, along with other critical infrastructure systems, is growing increasingly dependent upon the Internet and other network connections for data communication and monitoring systems [16, 32-35]. While this allows electrical suppliers convenient operation and management of systems, it increases the grid's susceptibility to cyber-attack, which exploit critical infrastructure systems, causing denial of webpage services to consumers, disruption to supervisory control and data acquisition (SCADA) operating systems, or sustained widespread power outages $[16,18,36,37]$. Unlike a physical attack, cyber attackers are capable of penetrating critical electric infrastructure from remote regions of the world, requiring only an Internet connection to gain pathways and install malware into the electric power grid's control systems. Many efforts are underway to harden the grid from such attack $[17,21,35]$. However, the integrated nature of the grid, which is based on centralized generation, but diffuse transmission, makes the entire system vulnerable to a concentrated attack, in contrast to a natural disaster that may have local or regional impacts. The U.S. Department of Homeland Security reports responding to approximately 200 cyber incidents in 2012 across critical infrastructure sectors, of which $41 \%$ involved the electrical grid [38]. Economic impacts of a successful breach are estimated to cost $\$ 243$ billion mounting to roughly \$1 trillion in an extreme case [39]. According to senior intelligence officials, various nation states (e.g. China, Russia, North Korea) have made attempts to map current critical infrastructure for future navigation and control of the U.S. electrical system [31]. Due to such offensive efforts, several other countries, including the U.S., have added cyber-attacks into their current military defense preparations [33].

As cyber-attacks are becoming increasingly prevalent, it is necessary to recognize the unpreparedness of critical infrastructure operators. In 2008, the Federal Energy Regulatory Commission (FERC) alongside the North American Electric Reliability Corporation (NERC) implemented a mandatory Critical Infrastructure Protection (CIP) Reliability Standards program [40]. Then an Executive Order (EO 13636) was implemented in 2013, in effort to address additional protection measures not listed in the CIP Standards program [41]. Other proposed policy solutions to electric grid cyber vulnerability include better assessment of vulnerabilities and increased cyber security control through strong firewalls and monitoring systems [1,35,40].

The technical community has recommended a more direct solution to all of these threats for some time: distributed generation and microgrids [42-44]. Microgrids allow the generation system to separate from distribution during disturbance events. The system maintains a high level of service and performance while decreasing the chances of cascading failures and enables distributed generation without grid redesign [45-46], thereby making the entire grid more resilient. Solar photovoltaic (PV) systems, which generate electricity directly from sunlight [47], are an ideal distributed generation technology to provide power for such microgrids [48]. PV costs have dropped significantly [49-50], due to technical evolution, large-scale manufacturing [51] and a substantial learning curve [52-55]. Coupled with current decreasing battery costs [56-57], the transition to solar PV distributed generation microgrid systems can be highly economical [58-60]. 
Preprint: Emily W. Prehoda, Chelsea Schelly, Joshua M. Pearce. 2017. U.S. Strategic Solar Photovoltaic-Powered Microgrid Deployment for Enhanced National Security. Renewable \& Sustainable Energy Reviews 78, 167-175. DOI:10.1016/j.rser.2017.04.094

The policy dimensions of how to implement such technical solutions has been given far less attention than would be normally considered adequate for a national security risk as demonstrated by the dearth in the literature as compared to more conventional national security threats. To address this threat, this paper reviews the technical and economic viability of utilizing defense contracting for a start of a national transition to distributed generation in the U.S. The objective of this review is to provide a foundation for thinking of the electrical grid in terms of a security issue and how to use renewable energy sources to increase national security. First, the technical scale of electrical demand and the necessary solar PV system is analyzed in detail to meet the first level of strategic importance: the U.S. military. The current domestic geographic deployment of microgrid installations in the critical U.S. defense infrastructure is reviewed and compared to historical grid failures and existing and planned PV installations to mitigate that risk. Then the technical skills of the top 20 U.S. defense contractors is reviewed and analyzed for a potential contracting transition to grid fortification. Three case studies are presented (Lockheed Martin, Bechtel, and GE) to demonstrate how this transition could take place. A cost sensitivity is performed and the potential revenue increase for the current defense contracts of the top 20 U.S. contractors for 2014 is presented. Then, each of the remaining levels the current grid vulnerabilities is summarized and policy recommendations are made to demonstrate a path to a secure and hardened U.S. electric system made up of PVpowered microgrids.

\section{Methods and Calculations}

\subsection{Methods}

Electric load data for fiscal year 2014 was obtained from the U.S. Energy Information Administration (EIA) for: (1) military, (2) government, (3) critical infrastructure (systems defined as electric power, natural gas/oil production, telecommunications, transportation, water supply, banking and finance, transportation, emergency and government services, and agriculture [61], (4) industrial, (5) commercial, and (6) residential [62] to determine the scale of PV-powered microgrid fortification needed at each level of strategic importance. For level 1 (military) facilities, the Department of Defense (DOD) Title 10 USC 2911 requires military operations to obtain $25 \%$ of energy generation from renewable energy resources by 2025 [63]. Along with the DOD Title 10 USC 2911, the DOD implemented a secondary initiative of 3GW of renewable capacity by 2025 [64].

To determine the percentage of military facilities meeting national security thresholds, operational military bases (Army, Air Force, Navy, and Marine) were identified from military databases [65-67] and cross-referenced with current Department of Defense solar renewable energy existing installations and upcoming projects [65-67]. Information was tabulated to provide base location, PV installation capacity, and base population.

Next, data on past major U.S. power blackouts were collected [5] and geolocated with the following data: cost in damages, amount of states and customers affected, and the cause of blackout. Two shapefiles were obtained to analyze the national solar electrical security for strategic level 1 facilities: 1) a shapefile of the United States was obtained from the ArcGIS database [68], 2) a point shapefile of 2015 military bases was obtained from the DOD [69]. Power outage locations military bases were then transcribed to a map utilizing ArcMap version 10.3.1, and this geographic information systems (GIS) data was then overlaid with current military solar-PV installations to provide a map of national solar electrical security for strategic level 1 facilities.

In order to gauge the difficulty in obtaining 25\% (required by 2025), 50\%, and 100\% compliance with hardening of electrical security at these strategic level 1 facilities, FY 2014 Federal spending budget was collected to determine funds allocated towards DOD federal contracting services. A list of the top 25 federal contractors was obtained from the Federal Procurement Data System and is arranged by the total federal contracting spending (and percentage) on services for each company for fiscal year 2014 [70]. Technical skills of three of the top 25 U.S. defense contractors (Lockheed Martin, GE and the Bechtel Group) is reviewed and analyzed for a potential contracting transition to grid fortification and case studies are presented. A cost sensitivity is performed and the 
Preprint: Emily W. Prehoda, Chelsea Schelly, Joshua M. Pearce. 2017. U.S. Strategic Solar Photovoltaic-Powered Microgrid Deployment for Enhanced National Security. Renewable \& Sustainable Energy Reviews 78, 167-175. DOI:10.1016/j.rser.2017.04.094

potential revenue increase for the current defense contracts of the top 20 U.S. contractors for 2013 is presented. Then, reviewing policy relevant to military deployment of PV, policy recommendations are summarized to demonstrate a path to PV-powered microgrids for the necessary national security measures made possible by grid fortification.

\subsection{Calculations}

Nameplate capacity $\left(\mathrm{N}_{\mathrm{p}}\right)$ in $\mathrm{GW}$ for $\mathrm{p}=25 \%, 50 \%$, and $100 \%$ solar PV generation is given by:

$$
N_{p}=\left(\frac{P_{C}}{365 * f}\right) * 10^{-6}[G W / k W]=\left(\frac{(p * C)}{365 * f_{s}}\right) * 10^{-6}[G W / k W]
$$

Where the percent capacity $\left(\mathrm{P}_{\mathrm{C}}\right)[\mathrm{MWH} /$ day], is given by $\mathrm{p}$ is the percent calculated here for 25,50 , and $100 \%$ of the total capacity (C, in $\mathrm{kWh} /$ day from Table 2). The average solar flux for the state is $\mathrm{f}_{\mathrm{s}}$. In the U.S. $\mathrm{f}$ is approximately $4.5 \mathrm{kWh} / \mathrm{m}^{2} /$ day for non-tracking flat plate PV tilted south at the latitude to optimize yearly energy production, but states vary from 3.34 to $7.5 \mathrm{kWh} / \mathrm{m}^{2} /$ day and this was taken into account for bases within each state [71].

Data on average solar flux per state was obtained and geolocated with location of U.S. domestic military bases. Two shapefiles were obtained to analyze the national solar electrical security for strategic level 1 facilities: 1) a shapefile of outlined the United States was obtained from the ArcGIS database [68], 2) a point shapefile of 2015 military bases was obtained from the Department of Defense data catalogue [69] were then transcribed to a map utilizing ArcMap version 10.3.1, and this geographic Information Systems (GIS) data was then overlaid with current military solar-PV installations to provide a map of national solar PV potential for strategic level 1 facilities.

The investment (I) sensitivity for 25\%, 50\%, and 100\% solar PV generation was given by:

$\mathrm{I}=\mathrm{N}_{\mathrm{p}} \mathrm{W}$ [US\$]

Where $\mathrm{N}$ is given by equation 1 , and $\mathrm{w}$ is the cost per Watt, which ranges from $\$ 2.50 / \mathrm{W}$ to $\$ 0.25 / \mathrm{W}$ in $\$ 0.25 / \mathrm{W}$ increments.

\section{Results}

\subsection{Historic Effects of U.S. Blackouts and Scale of Strategic Components}

Table 1 illustrates the impact of four major U.S. grid failures along with the number of states effected, economic damages, population affected, cause of grid failure, and average number of days without power. 
Preprint: Emily W. Prehoda, Chelsea Schelly, Joshua M. Pearce. 2017. U.S. Strategic Solar Photovoltaic-Powered Microgrid Deployment for Enhanced National Security. Renewable \& Sustainable Energy Reviews 78, 167-175. DOI:10.1016/j.rser.2017.04.094

Table 1. Recent Major U.S. Power Blackouts. Compiled from [72,73].

\begin{tabular}{|l|l|l|l|l|l|}
\hline Year & $\begin{array}{l}\text { Number } \\
\text { of States } \\
\text { Affected }\end{array}$ & $\begin{array}{l}\text { Affected } \\
\text { Population } \\
\text { (Millions) }\end{array}$ & $\begin{array}{l}\text { Costs } \\
\text { (US\$ } \\
\text { Billion) }\end{array}$ & Cause & $\begin{array}{l}\text { Days without } \\
\text { Power }\end{array}$ \\
\hline 2003 & 8 & 50 & 6 & Tree Trimming & 4 \\
\hline 2011 & 13 & 3 & 15 & $\begin{array}{l}\text { Early Snow } \\
\text { Storm }\end{array}$ & 10 \\
\hline 2012 & 14 & 8.2 & 65 & Hurricane & 14 \\
\hline 2012 & 7 & 4.2 & 2.9 & Wind & 10 \\
\hline
\end{tabular}

Table 2 illustrates the electrical use for six levels of strategic importance. Data were obtained from the EIA for Fiscal Year (FY) 2013. Table 2 shows solar-PV capacity (in GW) required to provide $100 \%$ of the electrical needs by each military branch. Overall, to meet the electrical needs of all six levels over $2000 \mathrm{GW}$ is needed. To put these values in perspective, the U.S. solar industry has installed a total $22.7 \mathrm{GW}$ of solar capacity across the U.S [74]. There are currently 216 microgrid deployments across the U.S. with $1.948 \mathrm{GW}$ renewable energy capacity [75]. This represents $0.09 \%$ of the U.S. total installed solar capacity.

Table 2. Electrical use size and calculated PV capacity for six levels of strategic importance in the U.S. for Fiscal Year 2013.

\begin{tabular}{|l|l|r|l|}
\hline Level & Electrical Load & $\begin{array}{l}\text { Total Electricity } \\
\text { Used [MWH/day] }\end{array}$ & $\begin{array}{l}\text { Calculated PV to } \\
\text { Meet Demand [GW] }\end{array}$ \\
\hline 1 & Military & $81,399.4$ & 16.3 \\
\hline 2 & Government & $*$ & \\
\hline 3 & Critical Infrastructure & 2620000 & 524 \\
\hline 4 & Industrial & 3720000 & 744 \\
\hline 5 & Commercial & 3840000 & 768 \\
\hline 6 & Residential & & \\
\hline
\end{tabular}

Military electrical use was obtained from the 2014 DOD Annual Energy Report [64], Electrical consumption for Industry, Commercial, and Residential sectors was obtained from [62]

* Electrical consumption alone is not available for the Federal Government and Critical Infrastructure, but divisions of each are included in industrial and commercial values.

The technical solutions to obtain compliance with hardening of electrical security at critical facilities is discussed below. For this review study, only level 1 (military base) loads are analyzed in more depth.

\subsection{Department of Defense}

The DOD operates over 400 military installations (not including air strips, outlying airfields, and training ranges) within the continental U.S. Of these, 27 active bases (9\%) have implemented or have current plans to implement solar-PV systems for onsite renewable energy generation (Table 3). 
Preprint: Emily W. Prehoda, Chelsea Schelly, Joshua M. Pearce. 2017. U.S. Strategic Solar Photovoltaic-Powered Microgrid Deployment for Enhanced National Security. Renewable \& Sustainable Energy Reviews 78, 167-175. DOI:10.1016/j.rser.2017.04.094

Table 3. Current Military Bases Solar-PV Systems

\begin{tabular}{|c|c|c|}
\hline & Power (MW)* & Population** (Thousands) \\
\hline \multicolumn{3}{|l|}{ Army } \\
\hline Fort Benning & 30 & 110 \\
\hline Fort Campbell & 5 & 84 \\
\hline Fort Carson & 2 & 124 \\
\hline Fort Detrick & 15 & 10 \\
\hline Fort Dix & 0.8 & 7 \\
\hline Fort Gordon & 30 & 94 \\
\hline Fort Hood & 1 & 322 \\
\hline Fort Huachuca & 17.2 & 33 \\
\hline Fort Rucker & 0.051 & 24 \\
\hline Fort Stewart & 30 & 54 \\
\hline Presidio & 0.37 & 5 \\
\hline West Point & 0.56 & 10 \\
\hline \multicolumn{3}{|l|}{ Navy } \\
\hline China Lake & 13.78 & 5 \\
\hline Coronado & 0.924 & 27 \\
\hline Kings Bay & 30 & 16 \\
\hline Pearl Harbor & 2.4 & 58 \\
\hline $\begin{array}{l}\text { Saufley Field- Pen- } \\
\text { sacola }\end{array}$ & 50 & 14 \\
\hline Holley Field- Whiting & 40 & 16 \\
\hline \multicolumn{3}{|l|}{ Air Force } \\
\hline U.S. AFA & 6 & 7 \\
\hline Davis-Monthan & 16.4 & 16 \\
\hline Edwards AFB & 3.39 & 22 \\
\hline Eglin AFB & 30 & 17 \\
\hline Hill AFB & 0.22 & 24 \\
\hline LA AFB & 0.36 & 5 \\
\hline Luke AFB & 15 & 12 \\
\hline Nellis AFB & 14.2 & 29 \\
\hline \multicolumn{3}{|l|}{ Marine Corps } \\
\hline Albany MC Logistics & 46 & 23 \\
\hline Twenty-Nine Palms & $4.5^{\square}$ & 58 \\
\hline MC Air Station Miramar & 0.204 & 12 \\
\hline Barstow MCLB & 1.2 & 2 \\
\hline
\end{tabular}

* Data obtained from respective division databases for existing and near term planned [65-67].

** Data obtained from DOD Military Installations data bank represents proposals for upcoming solar PV generation capacities 
Preprint: Emily W. Prehoda, Chelsea Schelly, Joshua M. Pearce. 2017. U.S. Strategic Solar Photovoltaic-Powered Microgrid Deployment for Enhanced National Security. Renewable \& Sustainable Energy Reviews 78, 167-175. DOI:10.1016/j.rser.2017.04.094

Following the renewable energy production mandates noted above, each branch generated individual renewable energy generation goals to improve efficiency and national security. For example, the Department of the Navy plans to generate 50\% of their electricity needs from renewable energy by 2020 [76] and the Army's goal is 1 GW by 2025 [77]. By 2013, the DOD had 0.13GW of solar power up and running [78] and by 2015, the DOD deployed $0.583 \mathrm{GW}$ of renewable energy with microgrids [75]. Current solar energy generations for each military branch are as follows: Navy with 0.058GW, Army with 0.036GW, Air Force with 0.036 GW, and Marine Corps with 0.05194 [78]. With the addition of $0.12 \mathrm{GW}$ in upcoming solar projects [65-67], the U.S. DOD solar capacity accounts for only a small fraction, $1.1 \%$, of the current total U.S. solar capacity. This accounts for only a fraction (10\%) of the 3GW solar capacity goal for 2025.

\subsubsection{Current Defense Vulnerabilities to Grid Failure}

The DOD is heavily reliant on the electrical grid; DOD operations and facilities' electrical consumption is approximately $80 \%$ of total Federal energy consumption [64]. Along with high energy costs, the DOD obtains a majority of its energy from foreign fossil fuels with vulnerable supply lines. Nearly all current bases are vulnerable to electricity generation disruption. Many bases are located within regions that have already experienced major power outages, as can be seen in Figure 2. Extended power outages affect military operations: Failure in the electric grid renders equipment, weapons, and personnel defenseless to external attacks [65-67].

\subsubsection{Projected Solar PV Requirements for Military Grid Fortification}

Figure 3 shows a map of the United States military bases geolocated with average solar flux. As can be seen from Figure 3, there is a slight bias towards higher solar flux locations along with civilian population. Nameplate solar capacity was calculated utilizing previous DOD electrical demand (FY 2014). The varying percent capacities, $25 \%$ (required by 2025), 50\%, and 100\%, represent the solar capacity necessary for the DOD to transition to grid fortification. The solar PV nameplate capacities are: $\mathrm{N}_{25}=4.21 \mathrm{GW}, \mathrm{N}_{50}=8.42 \mathrm{GW}$, and $\mathrm{N}_{100}=16.9$ GW.

\subsubsection{U.S. Military Microgrid Cost Sensitivity}

A cost-sensitivity analysis was performed to illustrate the expected costs of implementing a renewable energy policy or program for the U.S. DOD. Cost-sensitivities were performed as a function of dollar per watt at each \% capacity (25, 50, and $100 \%$ ). The linear curve begins at $\$ 2.50 / \mathrm{W}$ and decreases by $\$ 0.25 / \mathrm{W}$ until it reaches $\$ 0.25 / \mathrm{W}$ to reflect potential future market costs of a microgrid system [70]. It should be noted here that these are projects as the cost of a large scale purchase of PV-powered microgrids on the order of tens of GW would benefit from considerable economics of scale both for the PV, storage system and any electronics or backup systems.

\subsection{Potential Microgrid Transition DOD Contractors}

A list of funds allocated to the top twenty-five DOD contractors was compiled to gauge the potentiality of transitioning to a solar PV microgrid system. In FY 2014, the DOD awarded \$286.41 billion, of total \$526.6 billion (FY 2014) budget, in funds to 100 contractors [70]. The top 25 are listed in Table 4, with the top awardee, Lockheed Martin Corporation, receiving over US\$25 billion. Bechtel Group Inc. was awarded almost US\$2.5 billion, followed by General Electric Company with US\$2.2 billion [70]. These three contractors were selected due to their existing penetration in renewable energy development programs and to illustrate existing specialized skills developed by defense contractors needed to aid the ease of transition to military grid fortification. 
Preprint: Emily W. Prehoda, Chelsea Schelly, Joshua M. Pearce. 2017. U.S. Strategic Solar Photovoltaic-Powered Microgrid Deployment for Enhanced National Security. Renewable \& Sustainable Energy Reviews 78, 167-175. DOI:10.1016/j.rser.2017.04.094

Table 4. Top 25 Federal Defense Contractors by funding

\begin{tabular}{|l|r|r|}
\hline DOD Contractor & $\begin{array}{l}\text { Financial Obligation } \\
\text { (USD) }\end{array}$ & \multicolumn{1}{l|}{$\begin{array}{l}\text { Number of } \\
\text { Projects }\end{array}$} \\
\hline LOCKHEED MARTIN CORPORATION & $\$ 25,065,461,247.84$ & 18,634 \\
\hline THE BOEING COMPANY & $\$ 18,005,350,332.68$ & 12,663 \\
\hline GENERAL DYNAMICS CORPORATION & $\$ 13,630,604,800.84$ & 16,329 \\
\hline RAYTHEON COMPANY & $\$ 11,816,577,883.63$ & 10,275 \\
\hline NORTHROP GRUMMAN CORPORATION & $\$ 9,213,821,365.01$ & 10,194 \\
\hline UNITED TECHNOLOGIES CORPORATION & $\$ 6,117,086,747.69$ & 9,296 \\
\hline L-3 COMMUNICATIONS HOLDINGS INC. & $\$ 5,288,631,065.98$ & 8,499 \\
\hline BAE SYSTEMS PLC & $\$ 4,876,213,940.43$ & 9,340 \\
\hline HUNTINGTON INGALLS INDUSTRIES INC. & $\$ 4,025,292,235.52$ & 3,116 \\
\hline HUMANA INC. & $\$ 3,527,209,086.24$ & 231 \\
\hline UNITEDHEALTH GROUP INCORPORATED & $\$ 3,203,771,598.01$ & 243 \\
\hline HEALTH NET INC. & $\$ 3,086,459,475.28$ & 129 \\
\hline SAIC INC. & $\$ 2,988,612,860.95$ & 13,789 \\
\hline UNITED LAUNCH ALLIANCE L.L.C. & $\$ 2,519,158,433.33$ & 89 \\
\hline BECHTEL GROUP INC. & $\$ 2,476,019,275.51$ & 153 \\
\hline GENERAL ELECTRIC COMPANY & $\$ 2,200,317,806.74$ & 4,649 \\
\hline BOOZ ALLEN HAMILTON HOLDING CORPORATION & $\$ 2,166,187,575.84$ & 4,507 \\
\hline EXELIS INC. & $\$ 2,105,471,497.30$ & 2,583 \\
\hline BELL BOEING JOINT PROJECT OFFICE & $\$ 2,018,971,983.94$ & 2,859 \\
\hline HEWLETT-PACKARD COMPANY & $\$ 1,766,447,587.13$ & 42,041 \\
\hline MCKESSON CORPORATION & $\$ 1,663,708,861.81$ & 16,139 \\
\hline ROYAL DUTCH SHELL PLC & $\$ 1,606,631,098.63$ & 489 \\
\hline TEXTRON INC. & $\$ 1,584,800,612.37$ & 3,717 \\
\hline GENERAL ATOMIC TECHNOLOGIES CORPORATION & $\$ 1,577,207,888.26$ & 707 \\
\hline
\end{tabular}

Data was collected from the FY 2014 Federal Procurement data system [65]. The report includes the Top 100 DOD contractors.

Many current DOD contractors already have a proven capacity for designing, building and commissioning PVpowered microgrids. Here, three cases studies of companies that currently contract with the U.S. military on renewable energy projects and thus have demonstrated capacity for these projects are reviewed in order to clarify the ability of defense contractors to provide these services to the U.S. military. These companies were selected only to demonstrate the vast array of all defense contractor's potential to bid on U.S. military solar PV research and development projects. To be clear this paper is not advocating for specific defense contractor companies, rather providing examples that demonstrate technical skills necessary for this transition.

\subsubsection{Lockheed Martin Corporation}

Lockheed Martin, a global security and aerospace company that provides a plethora of services to the DOD, has a Microgrid Development Center to improve efficiency, reliability, and security of microgrid systems. A demonstration project was implemented at Fort Bliss with expectations to decrease energy consumption by $20 \%$ [79-80]. Along with microgrid systems, Lockheed Martin has launched several solar power projects, including a back-up generation and storage unit for Fort Bliss. Lockheed Martin currently receives $8.7 \%$ funding of the total DOD Federal contracting budget. This amount of funding is significant when compared to the costs of U.S. military grid fortification. Even if this amount is held constant and shifted to microgrid deployment, as can be seen in Figure 4, Lockheed could fortify the entire U.S. military electrical infrastructure in a single year of expenditures if the system costs can be reduced to US\$1.50 or less. 
Preprint: Emily W. Prehoda, Chelsea Schelly, Joshua M. Pearce. 2017. U.S. Strategic Solar Photovoltaic-Powered Microgrid Deployment for Enhanced National Security. Renewable \& Sustainable Energy Reviews 78, 167-175. DOI:10.1016/j.rser.2017.04.094

\subsubsection{General Electric Company}

GE provides, among its diverse portfolio of electric energy technologies, clean energy technology and solutions, and has been involved in solar PV research for decades. More recently, GE has evolved to provide funding for solar projects as well as partnering with solar manufacturers to bring realized solar projects to customers. GE worked with DOD to develop a demonstration microgrid project at the Twentynine Palms Marine Corps Base. GE has opened the door to DOD installations, partnering with SunPower to build a 14.2 MW solar-PV system on the Nellis Air Force Base [81-82]. General Electric currently receives 0.8\% funding from the DOD Federal contracting budget.

\subsubsection{Bechtel Group Inc.}

Bechtel Group is a worldwide engineering, construction, and project management company, with expertise in infrastructure, defense and security, and power. A leader in nuclear fuel for over 70 years, Bechtel has introduced renewable technologies into their engineering profile. Bechtel has completed three major solar generating facilities across California, each above 100 MW capacity, delivering power to a collective 275,000 homes [83]. Bechtel currently receives $0.9 \%$ funding from the DOD Federal contracting budget.

The DOD awards approximately \$30 billion (10.4\%) of the DOD Federal contracting budget to these three companies annually. Even using an unreasonably conservative cost figure of US $\$ 4.00 / \mathrm{W}$ for an installed system of approximately 17GW, these three companies working together could complete 100\% U.S. military grid fortification in less than 2.5 years of current funding allotments. More realistically, such a massive infrastructure project would need to be spaced out over several years to control costs. To illustrate, consider a hypothetical model to fund compliance with $100 \%$ solar PV generation microgrids for U.S. military installations over 10 years. Total financial obligation spread across 10 years to design and deploy $100 \%$ solar PV capacity system is US\$42.0 billion as a function of US\$2.50/W, Figure 4. Projected DOD allocations include: US\$3.61 billion to Lockheed Martin, US\$336 million to General Electric Co., and US\$378 million to Bechtel Inc. each for ten years. It should be noted the careful balance that must be determined between limiting costs by extending the installation period and maintaining military grid vulnerability for an extended time and the effects on national security interests is left for future work. The model demonstrates projected financial obligations necessary to design and deploy renewable energy installations (utilizing Lockheed Martin, GE, and Bechtel Inc. as an example) to meet 100\% solar PV capacity by 2025.

\section{Discussion}

This study found the lack of electrical grid security poses significant risk to critical infrastructure systems. This section will discuss results that point to a need for increasing the U.S. military's electrical system resilience. The limitations of the study are included along with proposals for necessary future studies. Policy suggestions are included to assist the U.S. military's transition to aggressive solar PV generation. This review unveils one potential avenue to the military could take to improve components of national security, energy security, and energy costs.

\subsection{Expanding U.S. Military Electrical System Resilience}

There are significant threats of natural disaster, physical attack, and cyberattack to the U.S. electrical grid, as previously noted. Failures in the power system can result in detrimental supply shortages, economic impacts [84] and social costs [85]. It is important to design resilient infrastructure systems to recover service levels in a timely manner [86] and address mitigation of these extreme events [87]. Resilient technological systems are flexible, robust, prepared for change, and are essential to prosperous development of society [88]. Electrical system technology must improve, to provide increased energy security by preventing cascading grid failures [89].

The majority of military bases are still connected to the U.S. electrical grid and the vulnerable nature of the grid poses a serious threat to national security as personnel, daily operations, weapons, and essential equipment can 
Preprint: Emily W. Prehoda, Chelsea Schelly, Joshua M. Pearce. 2017. U.S. Strategic Solar Photovoltaic-Powered Microgrid Deployment for Enhanced National Security. Renewable \& Sustainable Energy Reviews 78, 167-175. DOI:10.1016/j.rser.2017.04.094

be compromised in a power outage [65-67]. The DOD spends billions of dollars in annual energy costs with the current electrical system model [64]. The DOD can transition to a more resilient system by installing decentralized automated microgrids primarily powered with solar PV at a one time, up front cost. This cost can be spread out over several years of deployment. If this is done, the cost of implementing solar PV installations will likely decrease because of the aggressive and protracted PV learning curve [52-55]. It is important to note that regardless of the deployment schedule these upfront costs will be recouped within a few years from avoided annual energy expenditures. The economics of this scale of deployment is left for future work as the focus of this study in on enhancing national security. Once disconnected, military base microgrids can provide sufficient generation by supplying enough energy to meet their electrical load and remain islanded in the event of grid failure [90]. Additionally, with appropriate planning, military bases can extend grid protection to surrounding communities. In the event of a power outage, military solar PV powered microgrids can act as a backup system and export surplus power to surrounding communities, helping regional resilience to grid disruption.

During times of low solar insolation, military operations still require power, and thus military microgrids will require adequate storage. Battery technology has been advancing rapidly, and now higher energy density $(700 \mathrm{Wh} / \mathrm{l})$ storage with $\mathrm{Li}$-ion is beginning to dominate. However, theoretical energy densities point to future improvements with nanostructures and new materials using abundant materials such as $\mathrm{LiS}(2600 \mathrm{Wh} / \mathrm{kg})$ and Liair $(11,000 \mathrm{Wh} / \mathrm{kg})$ technologies [91]. Along with these technological advancements, battery costs are dropping, with current costs being between $\$ 600-1,000 / \mathrm{kWh}$, and the DOE expects them to fall further to reach $\$ 225 / \mathrm{kWh}$ in 2020 and $\$ 150 / \mathrm{kWh}$ in the longer term [56]. Economies of scale will also factor into future battery prices, especially with Tesla's increased battery manufacturing plans through its GigaFactory, which plans to produce 500,000 batteries a year starting 2017 [92]. Shortly, battery packs (like the Power Wall), which will be ideal modular storage building blocks, are expected to be available for $\$ 350 / \mathrm{kWh}$ for home use [57]. Until Tesla batteries become available at the scale needed for the U.S. military, one temporary solution is the use of hybrid renewable energy systems to improve system efficiency and energy supply reliability [93]. More specifically, military installations can use combined heat and power (CHP) systems. During these low solar influx times, a CHP system turns on to maintain constant load [94] and these systems have been modeled with dispatch strategies [95] sufficient to cover even the most dynamic loads (e.g. a single family residences) [96-97]. Although the economics of hybrid PV+CHP+battery systems are attractive [98], CHP systems, are still subject to supply chain disruptions of the fuel source and should only be considered as temporary solutions. In addition, it is advisable to reduce loads as much as possible by instituting energy efficiency measures (as have been successful in the past at military bases) [99] and look at the potential for passive solar retrofits, which for example have worked for the Department of the Navy, creating energy savings [100,101]. Although thermal savings are not directly equivalent to electric load demand reductions, they do result in savings, for example, from reduced blower loads.

The DOD mandates 25\% renewable generation by 2025, along with a goal of 3GW across three branches. In Fiscal Year 2014, the DOD spent \$18.2 billion on all energy expenditures [64]. A significant fraction of these operating expenses would be offset by the capital expenditure of a PV-powered microgrid. Roughly 54\% of the DOD budget is allocated to DOD contracting. As can be seen from the results, utilizing current skills of top defense contractors, the DOD could shift funds to convert to 100\% solar-PV microgrid systems across Army, Navy/Marine Corps, and Air Force military bases, resulting in decreased costs. The remaining budget excess could be allocated to further harden energy security. The DOD can submit request for proposals (RFPs) to current DOD contractors that include research into optimal physical and cyber protection of solar-PV microgrid farms.

\subsection{Limits of Study and Future Work:}

The military is the first line of strategic importance for energy security. The results in this paper show that the overall expense is manageable within existing total budgets, but more granular estimates of costs are needed. A major limitation to this study is lack of data to calculate, on a case-by-case basis, solar PV generation capacity. 
Preprint: Emily W. Prehoda, Chelsea Schelly, Joshua M. Pearce. 2017. U.S. Strategic Solar Photovoltaic-Powered Microgrid Deployment for Enhanced National Security. Renewable \& Sustainable Energy Reviews 78, 167-175. DOI:10.1016/j.rser.2017.04.094

Detailed work is needed at each installation to determine the optimal solution for each base, which must take into account appropriate available areas for solar collection, current and future load profiles in small time steps and potential to reduce loads with energy efficiency retrofits. More precise and accurate estimates on the cost of PV-powered microrid system are needed at the GW scale, where, for example, industrial symbiosis benefits [102] are likely to occur. Careful ramping up of scale could produce templated (or even open source [103] ) designs that could be replicated in the future at much lower costs than the first round of demonstration systems. In addition, this analysis focused only on domestic DOD facilities and thus it should be expanded to all DOD facilities internationally.

Future work must address the feasibility of converting energy generation to a renewable solar source to meet the needs of critical infrastructures beyond military facilities addressing the other strategic areas shown in Figure 1. It is important to note that total Federal Government and Critical infrastructure electrical use is missing from the data set (Table 2) and future work is needed to quantify those values for strategic planning purposes. After this data is acquired, the additional loads and thus systems sizes for other government facilities would again increase the total scale of such systems, helping to attract more competition for contracts and better economies of scale on prices for both the defense and non-defense wings of the U.S. government.

\subsection{Policy}

Renewable energy policy in the DOD is still in its infancy, as Title 10 USC 2911 was implemented only in 2011 [63]. The DOD partnered with the Department of Energy and the National Renewable Energy Lab to develop renewable energy technology to cut costs, provide energy security, and comply with DOD mandates [104]. The DOD provides awards for research through the Strategic Environmental Research and Development program and energy projects through the Environmental Security Technology Certificate Program to fund military penetration into the renewable energy market [64]. A majority of current PV at military bases are grid-tied, and the majority of the power generated leaves DOD facilities through power purchase agreements. Although, the U.S. military has looked at the impact of improving sustainability with PV [105,106] as well as PV sources for military microgrids [107] and forward operating bases [108], it is still not commonly used as shown in this review. PV is well documented to increase security in a distributed network [109,110], which can be using a security by design [111] method with PV as a power source. There are limited policies in place to facilitate a transition to a dominant renewable energy generation system. Incentives to go off grid to owning, operating, and generating DOD’s own capacity through distributed microgrid technology would allow the military independence, reliability, and energy efficiency. Due to the critical nature of electrical power for the DOD policies should be examined to 1) minimize DOD electrical use by increasing efficiency wherever it would not hamper operations, 2) on the shortest time line possible transition to distributed PV-powered microgrid systems domestically wherever technically feasible. Policies to either increase DOD contractor rates to accomplish these two goals or shift current allotments to these priorities should be investigated both for DOD infrastructure domestically, but also internationally. Additional funding opportunities could be obtained by reforming allocation of funds. Chief of Naval operations, Admiral Jonathan Greenert and Chief of Staff General, Raymond Odierno argue the military is required to spend millions on unnecessary equipment and machinery $[112,113]$. The equipment accrues additional storage and maintenance costs. Suspending earmarked legislation would also provide funds to use for military solar PV development and implementation [114, 115]. It is well recognized that prioritization of defense contractor spending is a difficult task, but one that must occur while considering microgrids for U.S. military installations in order to achieve a better fortified electrical system.

\section{Conclusions}

The technical community recognizes the lack of electrical grid security and risks posed to critical infrastructure systems. Cascading grid failures elicit threats to national security, economic damages, and disruption to critical infrastructure systems. This paper compared the current geographic deployment of military installations to historical grid failures. This review highlights the need to think about the electrical grid in terms of security and utilizing renewable energy resources as a national security measure to counteract those vulnerabilities. A review 
Preprint: Emily W. Prehoda, Chelsea Schelly, Joshua M. Pearce. 2017. U.S. Strategic Solar Photovoltaic-Powered Microgrid Deployment for Enhanced National Security. Renewable \& Sustainable Energy Reviews 78, 167-175. DOI:10.1016/j.rser.2017.04.094

of current solar-PV penetration into United States Military bases illustrates the potential to mitigate future power outages by (1) maintaining an independent energy source and (2) providing a backup of surplus energy supply to civilians. The scale of electrical energy consumption and solar PV system necessary to meet electrical needs was analyzed for the United States Military. A minimal number of military bases have introduced solar PV systems to operate military operations, leaving large room for growth. A cost sensitivity was performed to estimate costs and potential savings in energy expenditures if the military transitions to $100 \%$ solar-PV energy generation. Three of the top 25 defense contractors were reviewed due to their penetration in renewable energy generation markets. These companies represent U.S. defense contractors' potential to respond to bids to complete solar PV research and development projects. The DOD can utilize a number of defense contracting companies technical skills to facilitate a national transition to renewable distributed generation microgrid systems. The technical and economic viability of this transition from the results of this review, indicate the DOD should investigate allocation of additional funds or shifting funds to utilize top defense contractors to begin a national transition to distributed solar PV generation. As the calculated costs of solar PV microgrid systems are a onetime upfront cost, the DOD can easily allocate funds across contracting companies, over ten years to meet $100 \%$ distributed renewable generation (rather than 25\%) compliance by 2025. The military can evolve their energy system to protect national security, provide energy security, and decrease energy costs.

\section{Acknowledgments}

The authors would like to acknowledge helpful discussions with P.J. Wilkins, V. Simon and S. Lockwood.

\section{References}

[1] Chen, G, Dong, Z, Hill, D, Zhang, G, Hua, K. Attack structural vulnerability of power grids: A hybrid approach based on complex networks. Physica A, 2010; 389(3):595-603.

[2] Wang, J, Rong, L. Cascade-based attack vulnerability on the US power grid. Safety Science 2009; 47(10): 1332-1336.

[3] O'Brien, G, Hope, A. Localism and Energy: negotiating approaches to embedding resilience in energy systems. Energy Policy 2010; 38(12): 7550-7558.

[4] Johansson, J, Jonsson, H, Johansson, H. Analysing the vulnerability of electric distribution systems: a step towards incorporating the societal consequences of disruptions. International Journal of Emergency Management 2007;4(1): 4-17.

[5] Amin, M. Energy Infrastructure Defense Systems. Proceedings of the IEEE 2005; 93(5): 861-875.

[6] Amin, M. Challenges in Reliability, Security, Efficiency, and Resilience of Energy Infrastructure: Toward Smart Self-Healing Electric Power Grid. Power and Energy Society General Meeting 2008; 1-5.

[7] Little, R. Toward more robust infrastructure: observations on improving the resilience and reliability of critical systems. System Sciences, Proceedings of the 36th Annual Hawaii International Conference 2002; 1-9.

[8] Albert, R, Albert, I, Nakarado, G. Structural Vulnerability of the North American Power Grid. Physical Review 2004; 69: 251031-251034.

[9] Brown, G, Carlyle, M, Salmerón, J, Wood, K. Analyzing the Vulnerability of Critical Infrastructure to Attack and Planning Defenses. INFORMS Tutorials in Operations Research 2014; 102-123.

[10] Amin, A. Security Challenges for the Electricity Infrastructure. Computer 2002; 35 (4): 8-10. 
Preprint: Emily W. Prehoda, Chelsea Schelly, Joshua M. Pearce. 2017. U.S. Strategic Solar Photovoltaic-Powered Microgrid Deployment for Enhanced National Security. Renewable \& Sustainable Energy Reviews 78, 167-175. DOI:10.1016/j.rser.2017.04.094

[11] Motter, A, Lai, Y. Cascade-based attacks on complex networks. Physical Review 2002; 66(6): 65102-165102-4.

[12] Salmeron, J, Wood, K, Baldick, R. Analysis of Electric Grid Security Under Terrorist Threat. IEEE Transactions on Power Systems 2004; 19(2): 905-912.

[13] Kinney, R, Crucitti, P, Albert, R, Latora, V. Modeling cascading failures in the North American power grid. The European Physical Journal 2005; 46(1): 101-107.

[14] Watts, D. Security \& Vulnerability in Electric Power Systems. North American Power Symposium 2003; 559-566.

[15] Fovino, I, Guidi, L, Masera, M, Stefanini, A. "Cyber security assessment of a power plant."Electric Power Systems Research, 81(2), 518-526, 2011.

[16] Sridhar, S, Hahn, A, Govindarasu, M. Cyber-Physical System Security for the Electric Power Grid. IEEE 2012; 100(1):

[17] Hebert, C. The Most Critical of Economic Needs (Risks): A Quick Look at Cybersecurity and the Electric Grid. The Electricity Journal 2013; 26(5): 15-19.

[18] Aitel, D. Cybersecurity Essentials for Electric Operators. The Electricity Journal 2013; 26(1): 52-58.

[19] Umbach,F. Energy infrastructure targeted as cyber attacks increase globally. World Review 2013; 5(3):.

[20] Onyeji, I, Bazilian, M, Bronk, C. Cyber Security and Critical Energy Infrastructure. The Electricity Journal 2014; 27(2): 52-60.

[21] Gent, M, Costantini, L. Reflections on Security. IEEE Power and Energy Magazine 2003; 1 (1): 46-52.

[22] Brummitt. C, Souza, R, Leicht, E. Suppressing cascades of load in interdependent networks. Proceedings of the National Academy of Sciences of the United States of America 2012; 109(12): 680-689.

[23] Executive Office of the President Report. Economic Benefits of Increasing Electric Grid Resilience to Weather Outages. 2013.

[24] Bernstein, A, Bienstock, D, Hay, D, Uzunoglu, M, Zussman, G. Sensitivity Analysis of the Power Grid Vulnerability to Large-Scale Cascading Failures. Performance Evaluation Review 2012; 40(3): 33-37.

[25] U.S. Federal Energy Regulatory Commission [Internet]. Electromagnetic Pulse: Effects on the U.S. Power Grid. 2015 [cited on 2015 Dec 7]. Available from: http://www.ferc.gov/industries/electric/indusact/reliability/cybersecurity/ferc executive summary.pdf.

[26] Detwiler, PK, editor. Failure to Protect U.S. Against Electromagnetic Pulse Threat Could Make 9/11 Look Trivial Someday [Internet]. Forbes: Energy; 2014 [cited 2015 Oct 17]. Available from: http://www.forbes.com/sites/peterdetwiler/2014/07/31/protecting-the-u-s-against-the-electromagnetic-pulsethreat-a-continued-failure-of-leadership-could-make-911-look-trivial-someday/.

[27] National Research Council [Internet]. Terrorism and the Electric Power Delivery System. Washington D.C.: 
Preprint: Emily W. Prehoda, Chelsea Schelly, Joshua M. Pearce. 2017. U.S. Strategic Solar Photovoltaic-Powered Microgrid Deployment for Enhanced National Security. Renewable \& Sustainable Energy Reviews 78, 167-175. DOI:10.1016/j.rser.2017.04.094

National Academies; 2012 [cited 2015 Oct 17]. Available from: http://www.wiresgroup.com/docs/reports/WPF Terrorism\%20and\%20The\%20Electric\%20Power\%20Delivery \%20System.pdf.

[28]Avalos, G, editor. PG\&E substation in San Jose that suffered a sniper attack has a new security breach [Internet]. San Jose Mercury News; 2014 [cited 2015 Oct 12]. Available from: http://www.mercurynews.com/business/ci 26419083/pg-e-substation-san-jose-that-suffered-sniper.

[29] CNN, Pagliery, J, editor. Sniper attack on California power grid may have been 'an insider,' DHS says [Internet]. CNN: Money; 2015 [cited on 2015 Oct 30]. Available from: http://money.cnn.com/2015/10/16/technology/sniper-power-grid/.

[30] Memmott, M, editor. Sniper attack on California power station raises terrorism fears [Internet]. NPR; 2014 [cited on 2015 Oct 12]. Available from: http://www.npr.org/sections/thetwo-way/2014/02/05/272015606/sniperattack-on-calif-power-station-raises-terrorism-fears.

[31] Wall Street Journal; Gorman, S, editor. Electricity grid in U.S. penetrated by spies [Internet]. Wall Street Journal; 2009 [cited on 2015 Oct 02]. Available from: http://www.wsj.com/articles/SB123914805204099085.

[32] Wu, F, Moslehi, K, Bose, A. Power System Control Centers: Past, Present, and Future. Proceedings of the IEEE 2005; 93(11): 1890-1908.

[33] Schainker, R, Douglas, J, Kropp, T. Electric utility responses to grid security issues. Power and Energy Magazine, IEEE 2006; 4(2): 30-37.

[34] Ulieru, M. Design for Resilience of Networked Critical Infrastructures. IEEE, Digital EcoSystems and Technologies Conference 2007: 540-545.

[35] Bessani, A, Sousa, P, Correia, M, Neves, N, Verissimo, P. The Crutial Way of Critical Infrastructure Protection. Security \& Privacy, IEEE 2008; 6(6): 44-51.

[36] Krotofil, M, Cardenas, A, Larsen, J, Gollmann, D. Vulnerabilities of cyber-physical systems to stale dataDetermining the optimal time to launch attacks. International Journal of Critical Infrastructure Protection 2014;7(4): 213-232.

[37] Wooi Ten, C, Manimaran, G, Ching Liu, C. Cybersecurity for Critcal Infrastructures: Attack and Defense Modeling. IEEE Transactions on Systems, Man and Cybernetics 2010; 40(4): 853-865.

[38] Bipartisan Policy Center; Hayden, M, Hebert, C, Tierney,S. Cybersecurity and the North American Electric Grid: Washington, DC: 2014. Print. New Policy Approaches to Address An Evolving Threat.

[39] Dipietro, B. Risk and Compliance Journal [Internet]. Wall Street Journal blog: Ben Dipietro. 2015 Jul [cited on 2015 Oct 17]. Available from: http://blogs.wsj.com/riskandcompliance/2015/07/08/attack-on-u-s-electricalgrid-could-cost-1-trillion/.

[40] Aradau, C. Security That Matters: Critical Infrastructure and Objects of Protection. Security Dialogue 2010; 41(5): 491-514.

[41] Spina, S, Skees, J. Electric Utilities and the Cybersecurity Executive Order: Anticipating the Next Year. The Electricity Journal 2013; 26(3): 61-71. 
Preprint: Emily W. Prehoda, Chelsea Schelly, Joshua M. Pearce. 2017. U.S. Strategic Solar Photovoltaic-Powered Microgrid Deployment for Enhanced National Security. Renewable \& Sustainable Energy Reviews 78, 167-175. DOI:10.1016/j.rser.2017.04.094

[42] Colson, C, Nehrir, M, Gunderson, R. Distributed multi-agent microgrids: a decentralized approach to resilient power system self-healing. IEEE $4^{\text {th }}$ International Symposium 2011: 83-88.

[43] Shahidehpour, M, Khodayar, M. Cutting campus energy costs with hierarchical control: the economical and reliable operation of a microgrid. IEEE Electrification Magazine 2013; 1(1): 40-56.

[44] Che, L, Shahidehpour, M. DC microgrids: economic operation and enhancement of resilience by hierarchical control. IEEE Transactions on Smart Grid 2014; 5(5): 2517-2526.

[45]Lasseter, R, Paigi, P. Microgrid: A conceptual solution. IEEE Power Electronics Specialist Conference 2004; 6: 4285-4290.

[46] Lasseter, RH. Microgrids and Distributed Generation. Journal of Energy Engineering 2007; 133(3): 144149.

[47] Pearce, JM. Photovoltaics—a path to sustainable futures. Futures 2002; 34(7): 663-674.

[48] Maity, I, Rao, S. Simulation and pricing mechanism analysis of a solar-power electrical microgrid. IEEE Systems Journal 2010; 4(3): 275-284.

[49] Barbose, G, Naïm RD, Weaver, S, Feldman, D, Margolis, R, Wiser, R. Tracking US photovoltaic system prices 1998-2012: a rapidly changing market. Progress in Photovoltaics: Research and Applications (2014).

[50] Reichelstein, S, Yorston, M. The prospects for cost competitive solar PV power. Energy Policy 2013; 55: 117-127.

[51] Zweibel, K, Mason, J, Fthenakis, V. A Solar Grand Plan. Scientific American 2008; 298, 64-73.

[52] Van der Zwaan, B, Rabl, A. Prospects for PV: a learning curve analysis. Solar Energy, 2003, 74(1), 19-31.

[53] Nemet, GF. Beyond the learning curve: factors influencing cost reductions in photovoltaics. Energy policy 2006;34(17): 3218-3232.

[54] Candelise, C, Winskel, M, Gross, R. The dynamics of solar PV costs and prices as a challenge for technology forecasting. Renewable and Sustainable Energy Reviews 2013; 26: 96-107.

[55] Nemet, G. Beyond the learning curve: factors influencing cost reductions in photovoltaics. Energy policy 2006; 34: 3218-3232

[56] U.S. Department of Energy, Grid Energy Storage, December 2013.

[57] Tesla. Energy storage for a Sustainable home [Internet]. PowerWall; 2015 [cited 2015 Nov 23]. Available from: http://www.teslamotors.com/powerwall.

[58] Chaurey, A, Kandpal, TC. A techno-economic comparison of rural electrification based on solar home systems and PV microgrids. Energy Policy 2010; 38(6): 3118-3129.

[59] Abu-Sharkh, S, Arnold, RJ, Kohler, J, Li, R, Markvart, T, Ross, JN, Yao, R. Can microgrids make a major contribution to UK energy supply?. Renewable and Sustainable Energy Reviews 2006; 10(2): 78-127.

[60] Su, B, Wu, T, Zhan, Z. The Optimal Allocation Model of Microgrid Based on Economic Benefits. In Intelligent Human-Machine Systems and Cybernetics (IHMSC), Sixth International Conference on IEEE 2014; 
Preprint: Emily W. Prehoda, Chelsea Schelly, Joshua M. Pearce. 2017. U.S. Strategic Solar Photovoltaic-Powered Microgrid Deployment for Enhanced National Security. Renewable \& Sustainable Energy Reviews 78, 167-175. DOI:10.1016/j.rser.2017.04.094

1: 300-303.

[61] Rinaldi, S, Peerenboom, J, Kelly, T. Identifying, Understanding, and analyzing critical infrastructure interdependencies. IEEE Control Systems Magazine 2001; 21(6): 11-25.

[62] U.S. Energy Information Administration. Short-Term Energy Outlook. EIA Independent Statistics and Analysis. 2015 Nov 10 [cited on 2015 Nov]. Available from: http://www.eia.gov/forecasts/steo/report/electricity.cfm.

[63] U.S. Government Publishing Office. Title 10 U.S.C. 2911 [Internet]. GPO; 2011 [cited on 2015 Oct 2]. Available from: http://www.gpo.gov/fdsys/granule/USCODE-2010-title10/USCODE-2010-title10-subtitleApartIV-chap173-subchapI-sec2911

[64] DOD Annual Energy Report, 2015. Depart of Defense.

[65] U.S. Army. [Internet] 2015 [cited on 2015 Oct 2]. Available from: www. http://www.goarmy.com/.

[66] U.S. Air Force. [Internet] 2015 [cited on 2015 Oct 2]. Available from: www. http://www.airforce.com/.

[67] U.S. Navy. [Internet] 2015 [cited on 2015 Oct 2]. Available from: www. http://www.navy.mil/.

[68] Fitzpatrick, C. US 50 States + DC shapefile. ArcGis Database. 2012 Feb 1 [cited on 2015 Oct 4]. Available from: https://www.arcgis.com/home/item.html?id=f7f805eb65eb4ab787a0a3e1116ca7e5.

[69] Department of Defense. Military Installations, Ranges, Training Areas. Data Catalog: Data.gov. 2015 Oct 8 [cited on 2015 Oct 10]. Available from: http://catalog.data.gov/dataset/military-installations-ranges-and-trainingareas.

[70] USA.gov. Top 100 Contractors Report. Federal Procurement Data System. 2015 [cited on 2015 Oct 2]. Available from: https://www.fpds.gov/fpdsng cms/index.php/en/reports/62-top-100-contractors-report3.html.

[71] Roberts, B.J. 2012. Photovoltaic Solar Resource of the United States. NREL. [cited on 2015 Oct 2]. Available from: http://www.nrel.gov/gis/images/eere pv/national photovoltaic 2012-01.jpg

[72] Andersson, G, Donalek, P, Farmer, R, Hatziargyriou, N, Kamwa, I, Kundur, K, Martins, N, Paserba, J, Pourbeik, P, Sanchez-Gasca, J, Schulz, R, Stankovic, A, Tayler, C, Vittal, V. Causes of the 2003 major grid blackouts in north America and Europe, and recommended means to improve system dynamic performance. IEEE Transactions on Power Systems 2005; 20(4): 1922-1928.

[73] Blake ES, Kimberlain TB, Berg RJ, Cangialosi JP, Beven JL. Tropical Cyclone Report Hurricane Sandy [Internet]. National Hurricane Center: 2013 [cited on 2015 Dec 3]. Available from: http://www.nhc.noaa.gov/data/tcr/AL182012 Sandy.pdf.

[74] Solar Energy Industries Association. Enlisting the sun: Powering the U.S. Military. Available at: http://www.seia.org/research-resources/enlisting-sun-powering-us-military-solar-energy-2013

[75] Saadeh, O. North American Microgrids 2015: Advancing Beyond Local Energy Optimization.Green Tech Media, Research Report, 2015.

[76] U.S. Navy [Internet]. U.S. Navy Energy, Environment, and Climate Change: 2009 [cited on 2015 Dec 7]. Available from: http://greenfleet.dodlive.mil/energy/. 
Preprint: Emily W. Prehoda, Chelsea Schelly, Joshua M. Pearce. 2017. U.S. Strategic Solar Photovoltaic-Powered Microgrid Deployment for Enhanced National Security. Renewable \& Sustainable Energy Reviews 78, 167-175. DOI:10.1016/j.rser.2017.04.094

[77] U.S. Army [Internet]. Army moves toward renewable energy goal for 2025: 2013 [cited on 2015 Dec 7]. Available from:

http://www.army.mil/article/94756/The_Army_Moves_Toward_Renewable_Energy_Goal_for_2025/.

[78] Solar Energy Industries Association. http://www.seia.org/research-resources/solar-industry-data, accessed 10/30/2015.

[79] Lockheed Martin. Intelligent Microgrid Solutions; U.S. Army and Lockheed Martin Commission microgrid at Fort Bliss [Internet]. 2013 Jan [cited on 2015 Oct 10]. Available from:

http://www.lockheedmartin.com/us/news/press-releases/2013/may/mfc-051613-us-armyand-LM.html.

[80] U.S. Army [Internet]. Fort Bliss unveils Army’s first microgrid: 2013 [cited on 2015 Dec 7]. Available from: http://www.army.mil/article/103577/Fort Bliss unveils Army s first microgrid/.

[81] Kwartin, B. Solar energy development on dod installations in the Mojave and colorado deserts. ICF International Technical Session 2011; 3: 1-30.

[82] General Electric Company. Solar 101: The Power of the Sun [Internet]. 2015 [cited on 2015 Oct 10]. Available from: https://renewables.gepower.com/solar-energy/overview/solar-101.html.

[83] Bechtel Corporation. Ivanpah Solar Electric Generating System California [Internet]. 2015 [cited on 2015 Oct 10]. Available from: http://www.bechtel.com/projects/ivanpah-solar-electric-generating-system/ .

[84] Arianos, S, Bompard, E, Carbone, A, Xue, F. Power grid vulnerability: A complex network approach. An Interdisciplinary Journal of Nonlinear Science 2009;19(1): 2-16.

[85] O'Brien, G, Hope, A. Localism and Energy: negotiating approaches to embedding resilience in energy systems. Energy Policy 2010; 38(12): 7550-7558.

[86] Avritzer, A, Carnevali, L, Ghasemieh, H, Happe, L, Haverkort, B, Koziolek, A, Menasche, D, Remke, A, Sarvestani, S, Vicario, E. Survivability evaluation of gas, water, and electricity infrastructures. Electronic Notes in Theoretical Computer Science 2015; 310: 5-25.

[87] McDaniels, T, Change, S, Cole, D, Mikawoz, J, Longstaff, H. Fostering Resilience to extreme events within infrastructure systems: Characterizing decision contexts for mitigation and adaptation. Global Environmental Change 2008; 18(2): 310-318.

[88] Marshall, N, Fenton, D, Marshall, P, Sutton, G. How Resource dependency can influence social resilience within a primary resource industry. Rural Sociology 2007; 72(3):359-390.

[89] Ang, B, Choong, W, Ng, T. Energy security: definitions, dimensions, and indexes. Renewable and Sustainable Energy Reviews 2015; 42: 1077-1093.

[90] Katiraei, F, Varennes, QC, Iravani, R, Hatziargyriou, N, Dimeas, A. Microgrids management.Power and Energy Magazine, IEEE 2008; 6(3): 54-65.

[91] Amine, K, Kanno, R, and Tzeng, Y, Rechargeable lithium batteries and beyond: Progress, challenges, and future directions, Materials Research Society Bulletin 2014; 39: 395-401.

[92] Tesla. Planned 2020 Gigafactory Production Exceeds 2013 Global Production [Internet]. 2014 [cited on 2015 Nov 23]. Available from: http://www.teslamotors.com/sites/default/files/blog attachments/gigafactory.pdf. 
Preprint: Emily W. Prehoda, Chelsea Schelly, Joshua M. Pearce. 2017. U.S. Strategic Solar Photovoltaic-Powered Microgrid Deployment for Enhanced National Security. Renewable \& Sustainable Energy Reviews 78, 167-175. DOI:10.1016/j.rser.2017.04.094

[93] Erdinc, O, Uzunoglu, M. Optimum design of hybrid renewable energy systems: overview of different approaches. Renewable and Sustainable Energy Reviews 2012;16(3): 1412-1425.

[94] Pearce, J. Expanding photovoltaic penetration with residential distributed generation from hybrid solar photovoltaic and combined heat and power systems. Energy; 34(11): 1947-1957.

[95] Nosrat, A, Pearce, JM. Dispatch strategy and model for hybrid photovoltaic and trigeneration power systems. Applied Energy 2011; 88(9): 3270-3276.

[96] Nosrat, AH, Swan, LG, Pearce, JM. Improved performance of hybrid photovoltaic-trigeneration systems over photovoltaic-cogen systems including effects of battery storage. Energy 2013;49: 366-374.

[97] Shah, KK, Mundada, AS, Pearce, JM. Performance of US hybrid distributed energy systems: Solar photovoltaic, battery and combined heat and power. Energy Conversion and Management 2015; 105: 71-80.

[98] Aishwarya S. Mundada, Kunal K. Shah, J.M. Pearce. Levelized Cost of Electricity for Solar Photovoltaic, Battery and Cogen Hybrid Systems. Renewable and Sustainable Energy Reviews (2016, in press).

[99] NREL Energy Projects, 2015. Available at: http://www.nrel.gov/defense/projects.html\#army.

[100] Wray, W, Miles, C. A passive solar retrofit study for the United States Navy. Solar World Forum Conference, Los Alamos Scientific Laboratory, 1981.

[101] DOD, Unified Facilities Criteria Report. Passive Solar Buildings. 2004.

[102] Pearce, J M. Industrial symbiosis of very large-scale photovoltaic manufacturing. Renewable Energy, 2008; 33(5): 1101-1108.

[103] Buitenhuis, AJ, Pearce, JM. Open-source development of solar photovoltaic technology. Energy for Sustainable Development, 2012; 16(3): 379-388.

[104] National Renewable Energy Laboratory. Department of Defense Energy Programs [Internet]. 2012 [cited on 2015 Dec 3]. Available from: http://www.nrel.gov/defense/projects.html.

105. Augenbroe G, Brown J, Elam M. Sustainable energy in military base design \& layout (Doctoral dissertation, Georgia Institute of Technology).

106. Gong Q, Lei J, Qiao H, Qiu J. Risk Assessment for Distribution Systems Using an Improved PEM-Based Method Considering Wind and Photovoltaic Power Distribution. Sustainability. 2017;9(4):1-5.

107. Eichenberg NT, Leger AS, Spruce J. Impacts of thermally efficient structures and photovoltaic sources in military microgrids. InPower Systems Conference (PSC), 2016 Clemson University 2016 Mar 8 (pp. 1-5). IEEE.

108. Asheim, J., 2016. The Future of Energy Efficiency in Marine Corps Forward Operating Bases. The University of Arizona.

109. Sheng W, Liu K, Cai Y, Du S. Risk-based Security Assessment in Distribution Network with the Integration 
Preprint: Emily W. Prehoda, Chelsea Schelly, Joshua M. Pearce. 2017. U.S. Strategic Solar Photovoltaic-Powered Microgrid Deployment for Enhanced National Security. Renewable \& Sustainable Energy Reviews 78, 167-175. DOI:10.1016/j.rser.2017.04.094

of Photovoltaic. InMATEC Web of Conferences 2016 Jan 1 (Vol. 55). EDP Sciences.

110. Shandan W, Zhao B, Xiaoyu X. Introduction to distributed photovoltaic power generation flexible gridconnection interface equipment research. InOnline Analysis and Computing Science (ICOACS), IEEE International Conference of 2016 May 28 (pp. 285-288). IEEE.

111. Veichtlbauer A, Langthaler O, Engel D, Kasberger C, Andrén FP, Strasser T. Towards applied Security-byDesign for DER units. InEmerging Technologies and Factory Automation (ETFA), 2016 IEEE 21st International Conference on 2016 Sep 6 (pp. 1-4). IEEE.

[1112] Carter, Ash. Secretary of Defense Testimony [Internet]. Department of Defense, Congressional Testimony 2015 Mar [cited on 2015 Dec 30]. Available from: http://www.defense.gov/News/Speeches/SpeechView/Article/606647/submitted-statement-senate-armed-services-committee-budget-request.

[113] Cox, M. Pentagon Tells Congress to Stop Buying Equipment it Doesn't Need [Internet]. Military.com 2015 Jan [cited on 2015 Dec 23]. Available from: http://m.military.com/daily-news/2015/01/28/pentagon-tellscongress-to-stop-buying-equipment-it-doesnt-need.html.

[114] Thornberry, M. DOD Reform: Highlights of the Thornberry Reform Effort [Internet] Committee on Armed Services, House of Representatives 2015 Mar [cited on 2015 Dec 30]. Available from: http://armedservices.house.gov/index.cfm?a=Files.Serve\&File id=6BA52738-8917-46EB-877784B1E6A704C4

[115] Bucci, S, Slattery, B, Maine, E. Progress is coming on defense acquisition reform [Internet]. The Heritage Foundation 2015 Apr [cited on 2015 Dec 30]. Available from:

http://www.heritage.org/research/reports/2015/04/progress-is-coming-on-defense-acquisition-reform\# ftn 
Preprint: Emily W. Prehoda, Chelsea Schelly, Joshua M. Pearce. 2017. U.S. Strategic Solar Photovoltaic-Powered Microgrid Deployment for Enhanced National Security. Renewable \& Sustainable Energy Reviews 78, 167-175. DOI:10.1016/j.rser.2017.04.094

\section{Figures}

Figure 1. Interdependency of infrastructure systems and electrical grid. Data compiled from literature on critical infrastructure industries [7, 9, $12,14,21,22]$.


Figure 2. Map of United States Military Bases with Solar-PV systems in historically vulnerable blackout zones. 
Preprint: Emily W. Prehoda, Chelsea Schelly, Joshua M. Pearce. 2017. U.S. Strategic Solar Photovoltaic-Powered Microgrid Deployment for Enhanced National Security. Renewable \& Sustainable Energy Reviews 78, 167-175. DOI:10.1016/j.rser.2017.04.094



Figure 3. Map of United States Military Bases geolocated with solar flux.

Figure 4. Total installation cost sensitivity as a function of installed cost and percent PV capacity on U.S. domestic military bases. Estimated solar PV costs were calculated as a function of cost per watt from \$2.50-\$0.25 reflecting current and expected market values for each percent capacity: $a=25 \%$, $b=50 \%, c=100 \%$.



